\title{
Pengetahuan dan Karakteristik Individu: Studi Cakupan Kepatuhan Minum Obat Paska Pemberian Obat Massal Pencegahan Filariasis di Kabupaten Tangerang
}

\author{
Individual Knowledge and Characteristics: Study of Compliance Scope in Taking \\ Medicines After Provision of Mass Drug Administration of Filariasis in Tangerang \\ Regency
}

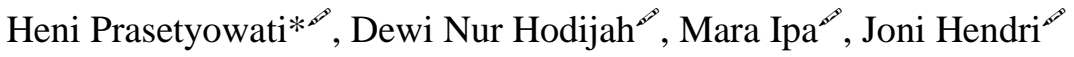 \\ Loka Penelitian dan Pengembangan Kesehatan Pangandaran \\ Jalan Raya Pangandaran Km 3 Desa Babakan, Kecamatan Pangandaran, Kabupaten Pangandaran, \\ Jawa Barat, Indonesia \\ *E_mail: myheraphie@gmail.com \\ Kontributor Utama
}

Received date: 11-07-2019, Revised date: 30-10-2019, Accepted date: 15-10-2019

\begin{abstract}
ABSTRAK
Kabupaten Tangerang sebagai salah satu kabupaten endemis filariasis telah menyelesaikan Pemberian Obat Pencegahan Masal (POPM) sebanyak lima putaran mulai tahun 2008 sampai dengan 2012. Kemunculan kembali kasus baru paska pemberian obat massal perlu diwaspadai dan diperlukan evaluasi terkait kepatuhan masyarakat dalam minum obat massal pencegahan serta pengetahuan dan karakteristik individu yang mempengaruhi. Tujuan penelitian untuk menganalisis hubungan pengetahuan dan karakteristik individu dengan keikutsertaan dan kepatuhan minum obat pencegah filariasis. Variabel yang dianalisis adalah karakteristik individu yang meliputi jenis kelamin, umur, status perkawinan, tingkat pendidikan, jenis pekerjaan serta variabel pengetahuan. Variabel tersebut dianalisa menggunakan uji regresi. Berdasarkan hasil wawancara 660 responden, hanya 54\% responden yang mengaku ikut serta dalam program POPM. Hasil analisis statistik menunjukkan jenis kelamin, umur responden serta pengetahuan memiliki hubungan yang signifikan terhadap keikutsertaan responden dalam program pengobatan filariasis. Dari 54\% responden yang ikut serta dalam POPM filariasis hanya $70 \%$ yang meminum semua obat yang diberikan. Semua variabel yang diuji tidak memiliki hubungan yang signifikan terhadap kepatuhan responden dalam meminum obat filariasis yang diterima. Keikutsertaan masyarakat dalam POPM masih dibawah target yang ditentukan, demikian pula kepatuhan masyarakat dalam meminum obat.
\end{abstract}

Kata kunci: pengetahuan, POPM, filariasis limfatik, kepatuhan

\begin{abstract}
Tangerang Regency as one of the endemic filariasis districts has completed provision of Mass Drug Administration (MDA) in five rounds from 2008 to 2012. The re-emergence of new cases after MDA needs to be monitored and evaluated, related to community compliance in taking preventive mass drugs as well as the knowledge and characteristics of influencing individuals. The aims of this study is to analyze the correlation of knowledge and characteristics of individuals with the participation and compliance of taking preventive filariasis drugs. The variables analyzed were individual characteristics which included gender, age, marital status, education level, type of work as well as knowledge variables. These variables were analyzed using a regression test. Based on the interview results of 660 respondents, only 54\% of respondents claimed to have participated in the POPM program. Statistical analysis showed that gender, age of respondents and knowledge had a significant correlation to the participation of respondents in the filariasis treatment program. Of the 54\% of respondents who participated in POPM filariasis, only $70 \%$ took all the drugs given. All variables tested did not have a significant relationship to the respondents' compliance in taking the received filariasis medication. Community participation in MDA is still below the specified target, as well as community compliance in taking drugs.
\end{abstract}

Keywords: knowledge, mass drug administration, lymphatic filariasis, compliance 


\section{PENDAHULUAN}

Filariasis merupakan penyakit tropis yang disebabkan oleh beberapa spesies mikrofilaria yaitu Brugia malayi, Brugia timori dan Wuchereria bancrofti. Penyakit ini menginfeksi jaringan limfe (getah bening) dan ditularkan oleh beberapa spesies nyamuk. Beberapa genus nyamuk yang berperan dalam penularan filariasis antara lain Culex, Anopheles, Mansonia dan Aedes. Di dunia terdapat 1,3 miliar penduduk yang berisiko tertular penyakit filariasis di lebih dari 83 negara. Sebanyak $60 \%$ kasus filariasis terjadi di Asia Tenggara. Indonesia merupakan salah satu negara endemis filariasis. Pada tahun 2017 terdapat 12.677 kasus filariasis di Indonesia. ${ }^{1}$

Eliminasi global untuk filariasis ditargetkan tercapai tahun 2020. Dalam rangka program eliminasi tersebut, kegiatan utama yang dilakukan adalah pemberian obat antifilarial secara masal untuk mengurangi sumber mikrofilaria. ${ }^{2}$ Tindak lanjut dari program eliminasi filariasis global, Indonesia telah melakukan kegiatan pengendalian filariasis melalui program Pemberian Obat Pencegahan Massal (POPM) filariasis di daerah endemis yang dilakukan satu kali dalam setahun selama lima tahun berturut-turut.

Hasil pemetaan daerah endemis di Indonesia tahun 2017 diperoleh sebanyak 236 kabupaten/kota merupakan daerah endemis yang tersebar di 28 provinsi, sedangkan daerah non endemis Filariasis adalah sebanyak 278 kabupaten/kota dari total 514 kabupaten/kota se-Indonesia. Hal ini menunjukkan bahwa sebagian dari penduduk Indonesia tinggal di daerah endemis sehingga berisiko tertular filariasis. Pada tahun 2017, terdapat 152 kabupaten/kota yang melaksanakan POPM filariasis. Hasil yang dicapai sampai tahun 2017 adalah 29 kabupaten/kota telah dinyatakan lulus dalam survei penilaian penularan tahap kedua dan sebanyak 78 kabupaten/kota berhasil menurunkan angka mikrofilaria menjadi kurang dari $1 \%{ }^{1}$

Upaya untuk mengeliminasi filariasis dengan program POPM membutuhkan tingkat kepatuhan minum obat yang tinggi. Penelitian di wilayah Puskesmas Bangko Pusako Pakan Baru menunjukkan bahwa walaupun cakupan POPM di Kecamatan Bangko Pusako sudah mencapai $80 \%$ namun hal ini baru data distribusi pembagian obat di Puskesmas. Survei yang menunjukkan bahwa obat tersebut benar benar di minum oleh masyarakat belum dilakukan. $^{3}$

Berbagai faktor berhubungan terhadap kepatuhan masyarakat meminum obat pencegahan filariasis. Salah satu faktor yang berhubungan dengan kepatuhan minum obat adalah faktor pengetahuan., ${ }^{4,5}$ Fakta di masyarakat menunjukkan bahwa tingkat pengetahuan cenderung berpengaruh dalam keputusan untuk mematuhi program pemberian obat pencegah filariasis. ${ }^{6}$

Kabupaten Tangerang merupakan salah satu kabupaten endemis filariasis di Provinsi Banten. Kabupaten ini telah menyelesaikan POPM sebanyak 5 putaran mulai tahun 2008 sampai dengan 2012 dan dua kali evaluasi dengan survei kajian penularan (Transmission Assesment Survey /TAS). Hasil evaluasi pengobatan menunjukkan bahwa kabupaten ini berhasil lulus dalam TAS 1 dan TAS 2. Hasil TAS yang dilakukan di Kabupaten Tangerang tidak ditemukan hasil positif mikrofilaria pada anak SD kelas 1 dan 2. ${ }^{7}$ Cakupan POPM Kabupaten Tangerang setiap tahunnya mencapai target baik secara cakupan epidemiologi dan geografi meskipun presentasenya menurun dibandingkan cakupan pada tahun pertama. Cakupan POPM berturutturut mulai tahun 2009 sampai 2013 adalah 94,89\%; 90,87\%; 91,62\%; 90,95\%; 89,80\%. ${ }^{8}$

Cakupan POPM yang tinggi di wilayah Kabupaten Tangerang menunjukkan bahwa distribusi obat pencegahan filariasis diterima oleh sebagian besar masyarakat. Keberhasilan POPM dapat mengurangi terjadinya transmisi filariasis limfatik, tetapi tidak dapat menghilangkan cacing dewasanya. ${ }^{9}$ Oleh karena itu pengobatan massal dilakukan setiap tahun minimal 5 tahun terkait siklus hidup cacing dalam tubuh manusia. ${ }^{10}$ Cakupan pengobatan massal membutuhkan tingkat kepatuhan yang baik minimal $65 \%$ masyarakat 
meminumnya, dan hal ini perlu dukungan sumber daya.

Hasil survei penularan (Tranmsission Assessment Survey/TAS) tahap 3, ditemukan 1 kasus positif. ${ }^{11}$ Hasil ini perlu diwaspadai terkait kemunculan kembali kasus baru, seperti yang terdokumentasi di beberapa wilayah lain. $^{12-14}$ Tujuan penulisan artikel ini adalah menganalisis hubungan pengetahuan dan karakteristik individu dengan keikutsertaan dan kepatuhan minum obat pencegah filariasis. Artikel ini diharapkan mampu memberi gambaran kepatuhan minum obat selama periode pengobatan massal serta faktor pengetahuan dan karakteristik individunya.

\section{METODE}

Artikel ini merupakan bagian dari penelitian "Studi Evaluasi Eliminasi Filariasis (Multicenter) Kabupaten Tangerang Provinsi Banten". Penelitian tersebut dilaksanakan selama sepuluh bulan mulai dari bulan Februari sampai dengan November 2017 di Desa Rajeg Kecamatan Rajeg dan Desa Kemiri Kecamatan Kemiri Kabupaten Tangerang. Kecamatan Rajeg merupakan daerah sentinel yaitu daerah ada penderita filariasis, sedangkan dan Kecamatan Kemiri merupakan daerah spot yaitu daerah yang secara geografis mirip dengan daerah sentinel namun tidak ada penderita. Data yang dianalisis dalam artikel ini merupakan hasil wawancara paska pengobatan massal tentang pengetahuan dan perilaku keikutsertaan dalam POPM filariasis dan kepatuhan minum obat. Total sampel untuk wawancara dalam penelitian ini adalah 660 responden. Wawancara menggunakan kuesioner terstruktur yang telah dikembangkan oleh WHO. Dari 660 sampel yang di wawancara selanjutnya diambil responden yang umurnya diatas 15 tahun, sehingga total sampel yang dianalisa adalah 517 responden. Pengambilan 517 sampel didasarkan pada kriteria eksklusi penelitian dimana responden dibawah usia 15 tahun tidak dilakukan wawancara tentang pengetahuan, hanya keikutsertaannya dalam POPM filariasis.
Variabel bebas yang dianalisis dalam penelitian ini meliputi pengetahuan, karakteristik individu, keikutsertaan dalam POPM filariasis dan perilaku minum obat berdasarkan pengakuan responden paska pengobatan massal. Karakteristik responden meliputi jenis kelamin, umur, pekerjaan, pendidikan dan status pernikahan. Pengetahuan responden meliputi pengetahuan penyebab filariasis, penularan filariasis, gejala filariasis, pengetahuan adanya program POPM filariasis. Variabel terikat adalah perilaku keikutsertaan dalam program POPM filariasis serta perilaku meminum obat pencegahan filariasis. Seluruh variabel bebas tersebut selanjutnya dianalisa untuk mengetahui hubungannya dengan keikutsertaan dan kepatuhan minum obat pencegah filariasis. Keikutsertaan yang dimaksud dalam penelitian ini adalah keikutsertaan responden dalam mendapatkan obat pencegahan filariasis baik secara aktif maupun pasif. Sedangkan kepatuhan minum obat adalah perilaku responden untuk meminum semua obat yang diberikan sesuai prosedur yang telah ditetapkan. Data tiap variabel dikategorikan untuk selanjutnya dianalisa secara statistik menggunakan analisis univariat dan analisis bivariat. Analisis bivariat dilakukan dengan uji regresi.

\section{HASIL}

\section{a. Karakteristik responden}

Analisis terhadap umur responden dilakukan dengan mengelompokkan responden dalam enam kelompok umur dengan interval 10 tahun. Hasil analisis menunjukkan responden yang paling banyak di wawancara adalah kelompok umur 25-34 tahun, dan paling sedikit diwawancara adalah kelompok umur $\geq 65$ tahun. Jumlah responden perempuan lebih banyak dibandingkan jumlah responden laki-laki. Jumlah responden dengan status kawin lebih banyak dibanding status belum kawin dan cerai. Distribusi kelompok umur, jenis kelamin dan status pernikahan responden tersaji dalam Tabel 1. 
Tabel 1. Distribusi kelompok umur, jenis kelamin dan status pernikahan responden

\begin{tabular}{|c|c|c|c|c|c|c|}
\hline \multirow{2}{*}{$\begin{array}{l}\text { Kelompok } \\
\text { Umur } \\
\text { (Tahun) }\end{array}$} & \multicolumn{2}{|c|}{ Jenis Kelamin } & \multicolumn{3}{|c|}{ Status Pernikahan } & \multirow[t]{2}{*}{ Total } \\
\hline & $\mathrm{L}$ & $\mathrm{P}$ & $\begin{array}{l}\text { Belum } \\
\text { Kawin }\end{array}$ & Kawin & Cerai & \\
\hline $15-24$ & $65(25,5 \%)$ & $53(20,2 \%)$ & $94(77 \%)$ & $22(6,5 \%)$ & $2(3,5 \%)$ & $118(22,8 \%)$ \\
\hline $25-34$ & $50(19,6 \%)$ & $72(27,5 \%)$ & $24(19,7 \%)$ & $86(2,4 \%)$ & $12(21 \%)$ & $122(23,6 \%)$ \\
\hline $35-44$ & $56(22 \%)$ & $46(17,6 \%)$ & $4(3,2 \%)$ & $92(27,2 \%)$ & $6(10,5 \%)$ & $102(19,7 \%)$ \\
\hline $45-54$ & $43(16,8 \%)$ & $56(21,4 \%)$ & 0 & $87(25,7 \%)$ & $12(21 \%)$ & $99(19,1 \%)$ \\
\hline $55-64$ & $26(10,2 \%)$ & $20(7,6 \%)$ & 0 & $34(10 \%)$ & $12(21 \%)$ & $46(8,9 \%)$ \\
\hline$\geq 65$ & $15(5,9 \%)$ & $15(5,7 \%)$ & 0 & $17(5 \%)$ & $13(22,8 \%)$ & $30(5,8 \%)$ \\
\hline Jumlah & $255(100 \%)$ & $262(100 \%)$ & $122(100 \%)$ & $338(100 \%)$ & $57(100 \%)$ & $517(100 \%)$ \\
\hline
\end{tabular}

Sumber : Hasil penelitian Studi Evaluasi Eliminasi Filariasis (Multicenter) Kabupaten Tangerang Provinsi Banten ${ }^{9}$

Terdapat delapan kategori jenis pekerjaan responden berdasarkan hasil wawancara yaitu Tidak Bekerja/Ibu Rumah Tangga, Pelajar, Tani/Buruh Tani, Karyawan, Wiraswasta, PNS dan lainnya. Sebagian besar responden berada dalam kategori tidak bekerja sedangkan kategori paling sedikit adalah PNS. Distribusi kategori pekerjaan responden tersaji dalam Tabel 2.

Tabel 2. Distribusi Kategori Pekerjaan Responden

\begin{tabular}{lcc}
\hline Jenis Pekerjaan & Jumlah & Persentase (\%) \\
\hline Tidak Bekerja & 118 & 22,8 \\
Ibu Rumah Tangga & 84 & 16,4 \\
Pelajar & 42 & 8 \\
Tani/Buruh Tani & 31 & 6 \\
Karyawan & 71 & 14 \\
Wiraswasta & 84 & 16 \\
PNS & 9 & 2 \\
Lainnya & 78 & 15 \\
\hline Jumlah & 517 & 100 \\
\hline
\end{tabular}

Tingkat pendidikan responden yang diwawancara beragam mulai dari tidak pernah sekolah sampai tamat perguruan tinggi. Sebagian besar responden yang di wawancara memiliki tingkat pendidikan tamat SD, hanya sekitar $4 \%$ yang memiliki pendidikan tamat perguruan tinggi. Distribusi tingkat pendidikan responden tersaji dalam Tabel 3. 
Tabel 3. Distribusi Pendidikan Responden

\begin{tabular}{|c|c|}
\hline Tingkat Pendidikan & Persentase $(\%)$ \\
\hline Tidak sekolah/Tidak tamat SD & 17 \\
\hline Tamat SD & 162 \\
\hline Tamat SLTP & 136 \\
\hline Tamat SLTA & 112 \\
\hline Tamat PT & 20 \\
\hline Jumlah & 517 \\
\hline $\begin{array}{l}\text { Berdasarkan hasil } \\
\text { pengetahuan responden terlihat bahwa 93\% } \\
\text { responden tidak mengetahui bahwa filariasis } \\
\text { disebabkan oleh cacing, sebanyak } 73 \% \\
\text { responden juga tidak mengetahui bahwa } \\
\text { penularan filariasis melalui perantara nyamuk, } \\
\text { sebagian besar responden sepakat bahwa } \\
\text { filariasis bukan merupakan penyakit turunan, } \\
\text { gangguan makhluk halus maupun karena } \\
\text { melanggar pantangan. Lebih dari 90\% } \\
\text { responden belum mengetahui gejala awal } \\
\text { filariasis. Hal itu terlihat masih banyaknya } \\
\text { responden yang menjawab gejala filariasis } \\
\text { hanya dari fisik yang sudah mengalami }\end{array}$ & $\begin{array}{l}\text { adanya pembengkakan tangan atau kaki } \\
\text { sebanyak } 70 \% \text {, demam } 34 \% \text {, pembengkakan } \\
\text { lipatan ketiak } 2 \% \text {, dan pembengkakan buah } \\
\text { dada atau skrotum } 2 \% \text {. } \\
\text { Berdasarkan hasil wawancara } \\
\text { responden, } 304(59 \%) \text { responden mengetahui } \\
\text { adanya program POPM, namun hanya } 277 \\
(54 \%) \text { responden yang ikut serta dalam } \\
\text { program POPM. Dari } 277 \text { responden tersebut } \\
\text { hanya } 194(70 \%) \text { responden yang meminum } \\
\text { semua obat yang diberikan selebihnya obat } \\
\text { tidak diminum atau diminum sebagian. Data } \\
\text { frekuensi pengetahuan dan perilaku responden } \\
\text { tersaji dalam Tabel } 5 .\end{array}$ \\
\hline
\end{tabular}
pembengkakan. Responden yang menjawab

Tabel 5. Pengetahuan dan Perilaku Responden terhadap POPM Filariasis

\begin{tabular}{|c|c|c|c|}
\hline No & Pengetahuan dan keikutsertaan POPM & Jumlah & Persentase \\
\hline \multirow[t]{16}{*}{1} & Pengetahuan tentang penyebab filariasis & & \\
\hline & a. Penyakit yang disebabkan oleh cacing & & \\
\hline & Ya & 34 & $7 \%$ \\
\hline & Tidak & 483 & $93 \%$ \\
\hline & b. Penyakit yang ditularkan oleh nyamuk & & \\
\hline & Ya & 142 & $27 \%$ \\
\hline & Tidak & 375 & $73 \%$ \\
\hline & c. Penyakit keturunan & & \\
\hline & Ya & 2 & $0,40 \%$ \\
\hline & Tidak & 515 & $99,60 \%$ \\
\hline & d.Penyakit akibat gangguan makhluk halus & & \\
\hline & Ya & 0 & $0 \%$ \\
\hline & Tidak & 517 & $100 \%$ \\
\hline & e. Penyakit karena melanggar pantangan & & \\
\hline & Ya & 0 & $0 \%$ \\
\hline & Tidak & 517 & $100 \%$ \\
\hline No & Pengetahuan dan keikutsertaan POPM & Jumlah & Persentase \\
\hline
\end{tabular}


a. Menyebabkan kaki atau tangan membesar

Ya

Tidak

b. Tidak menimbulkan gejala dan akibat pada tubuh

Ya

$7 \quad 1 \%$

Tidak

c. Menyebabkan demam \& tubuh lemah/sakit-sakit

Ya

Tidak

d.Menimbulkan pembengkakan pada lipat paha/ketiak

Ya

$\begin{array}{cr}8 & 2 \% \\ 509 & 98 \%\end{array}$

Tidak

e. Pembengkakan buah dada/skrotum

Ya

Tidak

Pengetahuan tentang pengobatan pencegahan penyakit kaki gajah

(filariasis) untuk semua penduduk di desa ini

Ya, mengetahui

Tidak mengetahui

4 Keikutsertaan POPM

\begin{tabular}{lccc} 
& Pernah & 277 & $54 \%$ \\
Tidak pernah & 240 & $46 \%$ \\
\hline $5 \quad$ Status Minum Obat & & $70 \%$ \\
Ya, diminum semua & 194 & $70 \%$ \\
Tidak diminum/hanya sebagian semua & 83 & $30 \%$ \\
\hline
\end{tabular}

Hasil analisis regresi menunjukkan informasi bahwa jenis kelamin, umur responden serta pengetahuan memiliki hubungan yang signifikan terhadap keikutsertaan responden dalam program pengobatan filariasis. Namun, semua variabel tersebut tidak memiliki hubungan yang signifikan terhadap kepatuhan responden dalam meminum obat filariasis yang diterima.

Tabel 6. Hubungan Karakteristik Responden Terhadap Keikutsertaan Pengobatan

\begin{tabular}{|c|c|c|c|c|}
\hline No. & Variabel & B & $\operatorname{Exp}(B)$ & $p$-value \\
\hline 1. & Jenis kelamin & .950 & 2.585 & .000 \\
\hline 2. & Umur & .316 & 1.372 & .000 \\
\hline 3. & Status pernikahan & -.193 & .824 & .387 \\
\hline 4. & Pendidikan terakhir & -.038 & .962 & .710 \\
\hline 5. & Pekerjaan & -.014 & .986 & .778 \\
\hline 6. & Pengetahuan & 1.685 & 5.391 & .000 \\
\hline
\end{tabular}


Tabel 7. Hubungan Karakteristik Responden Terhadap Kepatuhan Minum Obat

\begin{tabular}{clccc}
\hline No. & \multicolumn{1}{c}{ Variabel } & B & $\operatorname{Exp}(\mathrm{B})$ & $p$-value \\
\hline 1. & Jenis kelamin & -.090 & .914 & .790 \\
2. & Umur & -.141 & .868 & .236 \\
3. & Status pernikahan & .414 & 1.512 & .218 \\
4. & Pendidikan terakhir & -.112 & .894 & .407 \\
5. & Pekerjaan & .043 & 1.044 & .540 \\
6. & Pengetahuan & .266 & 1.305 & .361 \\
\hline
\end{tabular}

\section{PEMBAHASAN}

Peran serta masyarakat merupakan hal yang penting dalam keberhasilan program POPM filariasis. Peran serta masyarakat dalam keikutsertaannya pada sebuah program dipengaruhi oleh berbagai hal, salah satunya karakteristik individu. ${ }^{10-12}$ Hasil penelitian ini menunjukkan bahwa umur, jenis kelamin dan pengetahuan responden berhubungan dengan keikutsertaan dalam program POPM filariasis, namun tidak berhubungan dengan kepatuhan minum obat pencegah filariasis, sedangkan pendidikan, pekerjaan dan status perkawinan tidak berhubungan dengan keikutsertaan dan kepatuhan minum obat pencegah filariasis.

Pendidikan merupakan salah satu faktor yang tidak berhubungan dengan keikutsertaan responden dalam program POPM filariasis. Meskipun dalam beberapa sumber disebutkan bahwa semakin tinggi jenjang pendidikan, maka pemahaman mengenai partisipasi lebih baik dan berdampak pada tingkat partisipasi yang baik pula. ${ }^{12,13}$ Namun, dalam penelitian ini pendidikan responden bukan merupakan faktor yang mampu mendorong untuk ikut serta dalam program tersebut. Sebagian besar responden yang diwawancara menempuh pendidikan tingkat dasar, namun bersedia ikut serta dalam program POPM filariasis. Sriyono menyatakan banyak orang berpendidikan rendah namun mempunyai pola perilaku yang baik, hal ini karena adanya faktor pemahaman agama maupun pemahaman lainnya yang membentuk motivasi tersendiri dalam diri seseorang untuk melakukan suatu tindakan. ${ }^{14}$
Selain faktor pendidikan, jenis pekerjaan responden juga tidak berhubungan dengan keikutsertaan dan kepatuhan minum obat pencegah filariasis. Untuk mendapatkan obat dalam kegiatan POPM filariasis, responden ada yang secara aktif datang ke fasilitas kesehatan maupun secara pasif dibagikan oleh ketua RT/RW setempat. Keberadaan responden yang tidak bekerja serta ibu rumah tangga yang lebih banyak tinggal dirumah memungkinkan banyak informasi tentang program POPM yang diterima, ${ }^{5}$ baik secara aktif maupun pasif sehingga diharapkan lebih meningkatkan motivasi untuk berperan serta dalam POPM. Hasil serupa juga ditemukan di Kota Pekalongan bahwa tidak terdapat perbedaan yang signifikan antara pekerjaan dengan kepatuhan minum obat. ${ }^{14}$

Karakteristik individu seperti jenis kelamin, umur dan pengetahuan memiliki hubungan yang signifikan dengan keikutsertaan POPM filariasis. Berdasarkan hasil penelitian terlihat bahwa sebagian besar responden yang diwawancarai adalah usia produktif dengan jenis kelamin sebagian besar perempuan. Perbedaan jenis kelamin dan umur diduga membentuk persepsi yang berbeda sehingga mempengaruhi sikap dan pengetahuan yang berbeda juga. Usia produktif merupakan usia dimana kemampuan menerima hal-hal baru lebih cepat dibandingkan usia lanjut. ${ }^{15,16}$ Jenis kelamin tidak langsung mempengaruhi persepsi seseorang namun jenis kelamin mempengaruhi salah satu komponen dalam persepsi yaitu komponen afektif atau emosi. ${ }^{10}$ Hasil dalam penelitian ini berbeda 
dengan penelitian di kelurahan non endemis Kota Pekalongan. Dalam penelitian tersebut, faktor usia tidak berhubungan dengan kepatuhan POPM Filariasis. ${ }^{14}$

Hasil penelitian ini juga
menunjukkan
berhubungan dengan keikutsertaan dalam program POPM filariasis. Responden dengan pengetahuan POPM filariasis yang baik ikut serta dalam POPM filariasis. Namun keikutsertaan responden belum tentu diikuti dengan kepatuhan minum obat. Dalam kepatuhan minum obat pencegah filariasis, pengetahuan responden tidak memiliki hubungan yang signifikan. Hasil penelitian di Pekalongan, Muaro Jambi dan Batang Hari bahwa responden yang tidak patuh dalam meminum obat pencegahan filariasis, paling banyak ditemukan pada responden dengan pengetahuan tentang POPM buruk. ${ }^{17-19}$

Pengetahuan masyarakat yang rendah tentang filariasis menghambat kegiatan eliminasi filariasis. Beberapa masyarakat yang tidak mengetahui tentang penyebab filariasis beranggapan bahwa filariasis bukan penyakit menular, sehingga bila tidak ada anggota keluarga yang terkena filariasis maka mereka beranggapan bahwa tidak mungkin akan terkena filariasis. Pengetahuan masyarakat tentang penyebab penyakit filariasis, cara penularan dan program pengobatan di wilayah penelitian masih kurang. Berdasarkan hasil wawancara tentang pengetahuan responden terlihat bahwa sebagian besar responden tidak mengetahui bahwa filariasis disebabkan oleh cacing dan ditularkan melalui perantara nyamuk. Banyak pula responden yang menganggap bahwa filariasis tidak menular, atau bisa menular hanya dengan kontak fisik. Sebagian besar responden juga belum mengetahui gejala awal filariasis. Responden hanya mengetahui bahwa gejala filariasis hanya dari fisik yang sudah mengalami pembengkakan.

Cakupan POPM yang tinggi $(>85 \%)$ dalam program POPM filariasis diperlukan untuk meminimalisir penularan dan memberantas penyakit filariasis di Indonesia.
Cakupan POPM Kabupaten Tangerang setiap tahunnya mencapai target baik secara cakupan epidemiologi dan geografi. Persentase cakupan dalam lima tahun POPM dilaksanakan rata-rata berkisar $90 \%$. Cakupan tersebut sudah tergolong tinggi, yang berarti $90 \%$ masyarakat di Kabupaten Tangerang sudah mendapatkan obat pencegah filariasis. Namun berdasarkan hasil penelitian ini terlihat bahwa tidak seluruh masyarakat di wilayah penelitian mengetahui adanya program POPM, hanya 59\% masyarakat yang mengetahui adanya program tersebut. Jumlah ini mempengaruhi keikutsertaan masyarakat di wilayah penelitian dalam keikutsertaan program POPM di Kabupaten Tangerang yaitu hanya $54 \%$. Persentase keikutsertaan masyarakat tersebut masih di bawah angka cakupan yang dilaporkan. Berbagai alasan dikemukakan masyarakat tentang ketidakikutsertaanya dalam POPM Filarisasis. Alasan yang dikemukakan adalah kurangnya informasi, tidak berada di rumah, malas, takut efek samping dan lainlain. ${ }^{9}$

Hasil analisis statistik menunjukkan bahwa semua variabel karakteristik individu tidak berhubungan dengan kepatuhan minum obat pencegah filariasis. Hal ini menunjukkan bahwa kemauan responden dalam meminum obat pencegah filariasis tidak berhubungan dengan jenis kelamin, status pernikahan, pendidikan, umur, pekerjaan dan pengetahuan yang dimilikinya. Dalam penelitian ini, dari $54 \%$ masyarakat yang ikut serta dalam program POPM hanya $70 \%$ yang meminum semua obat yang di bagikan. Sedangkan responden lainnya mengaku tidak meminum obat yang diberikan atau hanya meminum sebagian obat yang diberikan. Alasan responden yang tidak meminum semua obat atau tidak minum obat yang diberikan petugas adalah karena takut efek sampingnya, sibuk bekerja, lupa dan lainnya. Hal yang serupa juga dilaporkan dalam studi pemberian obat masal pencegah filariasis di India bahwa tingkat kepatuhan masyarakat dalam program tersebut di Kabupaten Gulbarga berkisar antara $38,8-41,6 \%$. Beberapa alasan yang sama juga 
dikemukakan pada penelitian di India antara lain obat tidak diberikan atau individu tidak di rumah dan ketakutan akan efek samping. ${ }^{21}$

Masih banyaknya masyarakat yang tidak ikut serta dalam program POPM diduga karena pengetahuan mereka tentang manfaat program ini masih sangat minim. Seseorang yang berpengetahuan baik dalam masalah kesehatan (misalnya program pencegahan filariasis), akan lebih setuju untuk menelan obat filariasis karena mengetahui manfaat dan kegunaan obat tersebut jika dibandingkan dengan orang yang berpengetahuan rendah. ${ }^{3}$

Pengetahuan dan perilaku masyarakat terhadap pencegahan filariasis sangat mendukung keberhasilan program eliminasi filariasis, sehingga perlu adanya peningkatan pengetahuan dan mengurangi perilaku yang berisiko terhadap penularan filariasis. ${ }^{22}$ Beberapa hal yang penting tentang pengetahuan filariasis meliputi definisi penyakit, cara penularan, cara pencegahan, jenis pemeriksaan dan pengobatan harus secara lengkap diketahui. Sehingga masyarakat lebih mengetahui manfaat positif yang diperoleh dari pemberian obat tersebut. ${ }^{6}$

Penyebarluasan informasi tentang filariasis dapat dilakukan melalui promosi kesehatan yang disesuaikan dengan karakteristik masyarakat setempat dan disampaikan dengan bahasa yang mudah dipahami oleh penduduk. Promosi kesehatan terbukti telah dapat meningkatkan pengetahuan, sikap dan kepatuhan masyarakat dalam pengobatan filariasis. ${ }^{22}$ Pemberian promosi kesehatan secara langsung terhadap masyarakat diharapkan dapat meningkatkan sikap masyarakat terhadap upaya pencegahan penyakit filariasis. Pemberian promosi kesehatan di wilayah Subang terbukti berpengaruh signifikan terhadap sikap masyarakat dalam upaya pencegahan filariasis. $^{23}$

Sosialisasi adanya POPM di wilayah endemis filariasis sangat diperlukan. Tujuannya tidak lain menjadikan masyarakat faham akan manfaat program tersebut. Kurangnya sosialisasi dan rendahnya tingkat pengetahuan masyarakat terhadap filariasis menjadi faktor rendahnya keikutsertaan serta kepatuhan minum obat POPM filariasis di lokasi penelitian. ${ }^{24}$ Menurut Alamsyah dan Marlina variabel yang memiliki hubungan yang bermakna terhadap kepatuhan minum obat yaitu tingkat pengetahuan, jenis kelamin, pekerjaan, efek samping obat filariasis dan sosialisasi petugas kesehatan. ${ }^{3}$

Hasil penelitian ini menunjukkan adanya perbedaan angka cakupan POPM yang dilaporkan Dinas Kesehatan dengan hasil pengakuan responden di lokasi penelitian. Hal ini diduga karena adanya beberapa alasan berikut. Pertama, unit analisis data Dinas Kesehatan adalah kabupaten, sedangkan dalam penelitian ini unit analisisnya hanya wilayah sentinel saja sehingga data kabupaten merupakan angka rata-rata kabupaten, sedangkan pada penelitan ini hanya mengambarkan satu lokasi saja. Kedua, angka cakupan yang dilaporkan Dinas Kesehatan merupakan data obat yang diterima oleh warga berdasarkan catatan hasil distribusi, sedangkan pada penelitian ini merupakan data obat yang benar-benar diterima oleh warga berdasarkan hasil wawancara. Survey untuk memastikan bahwa obat anti filariasis diterima dan diminum oleh setiap warga masyarakat perlu dilakukan sebagai bahan evaluasi untuk eliminasi filariasis tidak hanya di Indonesia juga di negara-negara lain. ${ }^{25}$ Ketiga, penelitian ini bersifat wawancara yang terbatas pada daya ingat responden terhadap kejadian yang sudah berlalu (recall) sehingga kemungkinan ada bias bisa terjadi. Selain itu, mobilisasi yang tinggi di Kabupaten Tangerang memungkinkan tidak terjaringnya responden dalam penelitian ini yang menerima dan atau minum obat saat POPM berlangsung.

Beberapa faktor yang mampu meningkatkan cakupan pengobatan antara lain mengurangi dampak negatif akibat efek samping obat. Adanya ketakutan masyarakat diakibatkan adanya kasus kematian setelah mengkonsumsi obat massal pencegahan filariasis, berpengaruh signifikan terhadap penurunan cakupan pengobatan. Ditambah lagi 
pemberitaan media yang tidak seimbang mengenai kematian warga yang diduga merupakan Kejadian Ikutan Pasca Pengobatan (KIPP). ${ }^{25}$ Penelitian di India menunjukkan bahwa informasi yang disampaikan secara terus menerus melalui media umum meningkatkan cakupan pengobatan karena masyarakat mengetahui manfaat kegiatan pengobatan massal. Selain itu peningkatan cakupan minum obat juga perlu tenaga-tenaga kesehatan yang mengawasi kepatuhan minum obat dengan berbagai strategi. Dalam rekomendasi dari hasil penelitian di India disebutkan bahwa setidaknya ada tiga kunjungan lapangan wajib oleh petugas kesehatan selama program POPM. Kunjungan pertama untuk menciptakan kesadaran yang lengkap di kalangan masyarakat tentang program POPM filariasis. Kunjungan kedua untuk distribusi obat-obatan dan kepatuhan minum obat dan kunjungan ketiga untuk redistribusi obat ke orang yang belum meminum dan tindak lanjut terhadap efek samping jika ada. ${ }^{21}$

Studi post POPM filariasis bermanfaat sebagai proses monitoring dalam tahapan menuju eliminasi filariasis, antara lain untuk menilai keberlangsungan transmisi, identifikasi sumber penularan baru dan penyusunan model prediksi penularan. ${ }^{33-37}$ Evaluasi post POPM filariasis membantu memperkuat implementasi program eliminasi filariasis diwilayah endemis yang sedang berlangsung dan sebagai kewaspadaan di wilayah non endemis filariasis limfatik. $^{38}$

\section{KESIMPULAN}

Cakupan POPM filariasis berhubungan dengan karakteristik individu yaitu jenis kelamin, umur dan pengetahuan tetapi tidak berhubungan dengan kepatuhan dalam minum obat pencegah filariasis. Studi paska POPM filariasis memberi gambaran perlu adanya promosi kesehatan terkait filariasis limfatik untuk meningkatkan kesadaran masyarakat, selain itu sebagai kewaspadaan dini terkait faktor yang berhubungan dengan terjadinya transmisi.

\section{SARAN}

Perlu adanya sosialisasi dan strategi yang tepat di wilayah yang sedang melaksanakan POPM filariasis sehingga dapat meningkatkan cakupan dan kepatuhan minum obat masyarakat di wilayah tersebut.

\section{UCAPAN TERIMA KASIH}

Ucapan terima kasih penulis sampaikan kepada Kepala Badan Litbangkes RI selaku penyandang dana dalam pengumpulan data penelitian, Kepala Loka Litbangkes Pangandaran, Para Peneliti Loka Litbangkes Pangandaran serta semua pihak yang telah memfasilitasi pengumpulan dan penyusunan artikel ini.

\section{DAFTAR PUSTAKA}

1. Kementerian Kesehatan Republik Indonesia. Profil Kesehatan Indonesia Tahun 2015. Jakarta: Kementerian Kesehatan Republik Indonesia; 2016.

2. Abd Elaziz KM, El-Setouhy M, Bradley MH, Ramzy RMR, Weil GJ. Knowledge and practice related to compliance with mass drug administration during the Egyptian national filariasis elimination program. Am J Trop Med Hyg. 2013;89(2):260-4. doi: 10.4269/ajtmh.12-0491.

3. Alamsyah A. Marlina T. Faktor-faktor yang berhubungan denagn cakupan menelan obat massal pencegah filariasis. J Endur. 2016;1(1):17-22.

4. Ahdy MGR. Hubungan pengetahuan dan sikap tentang pencegahan filariasis dengan praktek minum obat dalam program pemberian obat masal pencegahan (POMP) filariasis Kelurahan Kuripan Kertoharjo Kota Pekalongan 2015 [Skripsi]. Semarang: Universitas Negeri Semarang; 2016.

5. Astuti EP, Ipa M, Wahono T, Ruliansyah A. Analisis perilaku masyarakat terhadap kepatuhan minum obat filariasis di tiga desa Kecamatan Majalaya Kabupaten Bandung Tahun 2013. Media Penelit dan Pengemb Kesehat. 2017;24(4):199-208. 
6. Syabriannur M, Musafaah, Fakhriadi R. Hubungan pengetahuan, sikap, dukungan keluarga dan akses pelayanan kesehatan dengan kepatuhan masyarakat minum obat antifilariasis [Internet]. Banjarbaru: Universitas Lambung Mangkurat; 2016. Diunduh dari: https://docplayer.info/80867632-Hubunganpengetahuan-sikap-dukungan-keluarga-danakses-pelayanan-kesehatan-dengan-kepatuhanmasyarakat-minum-obat-antifilariasis.html.

7. Subdit Filariasis dan Kecacingan. Rencana pre TAS Kabupaten/Kota. Jakarta: Ditjen P2 PL Kementerian Kesehatan RI; 2012.

8. Dinas Kesehatan Kabupaten Tangerang. Cakupan POPM filariasis 2009-2013 Kab Tangerang. Kabupaten Tangerang: Dinas Kesehatan Kabupaten Tanggerang; 2014.

9. Ottesen EA, Hooper PJ, Bradley M, Biswas G. The global programme to eliminate lymphatic filariasis health impact after 8 years. PLoS Negl Trop Dis. 2008;2(10):e317. doi: 10.1371/journal.pntd.0000317.

10. Michael E, Malecela-Lazaro MN, Simonsen PE, Pedersen EM, Barker G, Kumar A, et al. Mathematical modelling and the control of lymphatic filariasis. Lancet Infect Dis. 2004;4(4):223-34. doi: 10.1016/S14733099(04)00973-9.

11. Ditjen P2PTVZ Kemenkes RI. Laporan survei penilaian penularan filariasis (TAS-3) di Kabupaten Tangerang. Jakarta: Kementerian Kesehatan RI; 2018.

12. Rao RU, Nagodavithana KC, Samarasekera SD, Wijegunawardana AD, Premakumara WD, Perera SN et al. A comprehensive assessment of lymphatic filariasis in Sri Lanka six years after cessation of mass drug administration. PLoS Negl Trop Dis 2014; 8(11):e3281. doi:101371/journal.pntd 0003281.

13. Simonsen PE, Derua YA, Magesa SM, Pedersen EM, Stensgaard AS, Malecela MN, et al. Lymphatic filariasis control in Tanga Region, Tanzania: status after eight rounds of mass drug administration. Parasit Vectors. 2014;7:507. doi: 10.1186/s13071-014-0507-5.

14. Upadhyayula SM, Mutheneni SR, Kumaraswamy S, Kadiri MR, Pabbisetty SK, Yellepeddi VS. Filaria monitoring visualization system: a geographical information system-based application to managelymphaticfilariasis in Andhra Pradesh, India. Vector Borne ZoonoticDis.
2012;12(5):418-27.

doi: 10.1089/vbz.2011.0713.

15. Ipa M, Prasetyowati H, Hendri J, Hodijah DN, Astuti EP, Ridwan W, et al. Studi evaluasi eliminasi filariasis (Multicenter) Kabupaten Tangerang Provinsi Banten [Laporan Penelitian]. Pangandaran: Loka Litbang P2B2 Ciamis; 2017.

16. Monintja TCN. Hubungan antara karakteristik individu, pengetahuan dan sikap dengan tindakan PSN DBD masyarakat Kelurahan Malalayang I Kecamatan Malalayang Kota Manado. JIKMU. 2015;5(2b):503-19.

17. Jatmiko YA. Pengaruh karakterisitik masyarakat terhadap partisipasi pemeliharaan saluran lingkungan di Desa Bandungrejo, Kecamatan Mranggen, Kabupaten Demak. J Pembang Wil Kota. 2017;13(2):257-68.

18. Hayana, Marlina H, Kurnia A. Hubungan karakteristik individu dan lingkungan sosial terhadap perilaku buang air besar sembarang. J Kesehat Komunitas. 2018;4(1):8-15. doi:10.25311/keskom.Vol4.Iss1.195.

19. Mufidati H. Faktor-faktor yang berhubungan dengan persepsi masyarakat mengenai filariasis di RW 03 Desa Cimanggis [Skripsi]. Jakarta: UIN Syarif Hidayatullah; 2016.

20. Tombokan V, Rattu AJM, Tilaar CR. Faktorfaktor yang berhubungan dengan kepatuhan berobat pasien diabetes melitus pada praktek dokter keluarga di Kota Tomohon. JIKMU. 2015;5(3):260-9.

21. Nurlaila, Ginandjar P, Martini. Faktor-faktor yang berhubungan dengan kepatuhan pengobatan masal di kelurahan non endemis filariasis Kota Pekalongan. J Kesehat Masy. 2017;5(4):455-66.

22. Normadewi B. Analisis pengaruh jenis kelamin dan tingkat pendidikan terhadap persepsi etis mahasiswa akuntansi dengan love of money sebagai variabel intervening [Tesis]. Semarang: Universitas Diponegoro; 2012.

23. Iswanto F, Rianti E, Musthofa SB. Faktorfaktor yang berhubungan dengan perilaku pencegahan filariasis pada masyarakat di Kecamatan Bonang Kabupaten Demak. J Kesehat Masy. 2017;5(5):990-99.

24. Nurlaila, Ginandjar P, Martini. Faktor-faktor yang berhubungan dengan kepatuhan pengobatan masal di kelurahan non endemis 
filariasis Kota Pekalongan. J Kesehat Masy. 2017;5(4):455-66.

25. Arini, Saraswati LD, Ginandjar P, Martini. Prevalensi filariasis dan gambaran pengobatan masal di wilayah kerja Puskesmas Jembatan Mas Kabupaten Batang Hari. J Kesehat Masy. 2018;6(1):178-90.

26. Sakinah E. Perilaku dalam pencegahan filariasis di wilayah kerja Puskesmas Muara Kumpeh Kabupaten Muaro Jambi tahun 2014. Sci J. 2015;4(1):37-43.

27. Patel PK. Mass drug administration coverage evaluation survey for lymphatic filariasis in Bagalkot and Gulbarga Districts. Indian $\mathbf{J}$ Community Med. 2012;37(2):101-6. doi: 10.4103/0970-0218.96095.

28. Santoso, Taviv Y, Yahya, Mayasari R. Pengaruh promosi kesehatan terhadap pengetahuan, sikap dan perilaku masyarakat tentang filariasis. Bul Penelit Sist Kesehat. 2014;17(2):167-76.

29. Utami NW. Pengaruh promosi kesehatan tentang filariasis terhadap sikap masyarakat dalam upaya pencegahan penyakit filariasis di daerah pantura Kabupaten Subang [Skripsi]. Sukoharjo: Universitas Muhammadiyah Surakarta; 2015.

30. Andriani S. Faktor-faktor yang berhubungan dengan kepatuhan minum obat filariasis di Desa Kenual Kecamatan Nanga Pinoh Kabupaten Melawi Tahun 2015 [Skripsi]. Pontianak: Universitas Muhammadiyah Pontianak; 2015.

31. Silumbwe A, Zulu JM, Halwindi H, Jacobs C, Zgambo J, Dambe R, et al. A systematic review of factors that shape implementation of mass drug administration for lymphatic filariasis in sub-Saharan Africa. BMC Public Health. 2017;17(1):484. doi: 10.1186/s12889017-4414-5.
32. Ipa M, Astuti EP, Hakim L, Fuadzy H. Analisis cakupan obat massal pencegahan filariasis di Kabupaten Bandung dengan pendekatan model sistem dinamik. BALABA. 2016;12(1):31-8. doi: 10.22435/balaba.v12i1.4470.31-38.

33. Srivastava PK, Krishamoorthy K, Govenkar S, Perni S, Dalvi S, Subramanain S, et al. Elimination of lymphatic filariasis in Goa: first successful transmission assessment survey in India. J Commun Dis. 2014;46(2):7-16.

34. Shamsuzzaman AK, Haq R, Karim MJ, Azad MB, Mahmood AS, Khair A, et al. The significant scale up and success of transmission assessment surveys 'TAS' for endgame surveillance of lymphatic filariasis in Bangladesh: one step closer to the elimination goal of 2020. PLoS Negl Trop Dis. 2017;11(1):e0005340.

doi: 10.1371/journal.pntd.0005340.

35. Khieu V, Or V, Tep C, Odermatt P, Tsuyuoka $\mathrm{R}$, Char MC, et al. How elimination of lymphatic filariasis as a public health problem in the Kingdom of Cambodia was achieved. Infect Dis Poverty. 2018;7(1):15. doi: 10.1186/s40249-018-0394-7.

36. Ojha CR, Joshi B, Prakash K, Dumre SP, Yogi KK, Bhatta B, et al. Impact of mass drug administration for elimination of lymphatic filariasis in Nepal. PLoS Negl Trop Dis. 2017;11(7):e0005788. doi:10.1371/journal.pntd.0005788.

37. Aye NN, Lin Z, Lon KN, Nwe TW, Mon KM, Ramaiah K, et al. Mapping and modelling the impact of mass drug adminstration on filariasis prevalence in Myanmar. Infect Dis Poverty. 2018;7(1):56. doi: 10.1186/s40249-018-04209.

38. Srividya A, Subramanian S, Jambulingam P, Vijayakumar B, Dinesh Raja J. Mapping and monitoring for a lymphatic filariasis elimination program: a systematic review. Res Rep Trop Med. 2019;10:43-90. doi:10.2147/RRTM.S134186. 